\title{
Effect of Prednisolone on Muscles
}

\section{Toshio NAKATA}

The 2nd Department of Internal Medicine, Osaka University Medical School, Osaka, Japan

(Director : Prof. Mitsuo Nishikawa M.D.)

In daily urinary pool of rabbits, the ratio of excreted creatine to creatinine was found to have been raised by daily parenteral administration of $25 \mathrm{mg}$ of Prednisolone. In these animals, urinary recovery of creatine, orally loaded, was larger than in the control. This fact shows that the creatinuria in this case does not depend on an impaired synthesis but on decreased storage capacity.

Isotope technique was used to elucidate the storage capacity. Thirty minutes after a subcutaneous injection of $2 \mu \mathrm{C}$ (112 gamma) of $\mathrm{C}^{14}$-creatine to a male albino rat, the radioactivities were found in the lungs, heart, liver, kidneys, spleen, skeletal muscles with the exception of the brain. However, a. gradual increase in the radioactivities followed in the brain, heart and skeletal muscle, but a decrease in the other organs. Finally, 44 hrs after the injection, the distribution pattern of radioactivities to each tissue became identical to that of total creatine and creatine kinase.

These findings lead us to the conclusion that the creatinuria by prednisolone is due to the lowered ability of converting creatine to creatine phosphate-the fixed form in the tissues-, as a result of decrease in creatine kinase activity.

The decrease in enzyme activity was found in creatine kinase, aldolase, and Ca-ATPase of rabbit muscles by injection of prednisolone. The influence of the steroid on these enzymes is not necessarily equal in different tissues. The change was most significant in the back muscle followed by gastrocnemius, soleus, diaphragm and heart in decreasing order.

The color of the muscles was the deepest red in the heart, gradually fading in association with the decrease of myoglobin, succinic dehydrogenase activity, the ratio of GOTm to total GOT, the ratio of GPTm to total GPT, and the amount of $\mathrm{H}$ subunit in $\mathrm{LDH}$ in the above order. A composition of the heart is suitable for its tonic movement, and contrary, that of the back muscle for its phasic movement. It can be said, therefore, that the steroid exerts a stronger influence on the white color muscle with phasic movement.

(pp. 1150 1158) 


\title{
筋組織に及ぼす Prednisolone の影響
}

\author{
大阪大学医学部西川内科（主任 西川光夫教授） \\ 中 田俊士
}

(昭和 41 年 5 月 19 日受付)

I 緒 言

Glucocorticoid を長く投与すると，人工的な Gushing 症候群が惹起され，首や胴が脂肪の沈着で太り 逆に四肢は細くなつて，そこに所謂 Buffalo hump と名付けられる特異な像がみられて来る。乙の様な四 肢の瘦せは，通常筋肉の削瘦に依つており，その筋力にも低下がみられ，重篤な時には階段の昇降や，しや がんだ姿勢からの立上りが困難となつたり，鉛筆を持つことさえ出来なくなるといわれる。

ての様な筋の障碍は，大なり小なり，Glucocorticoid 投与に随伴して招来されるものであるが，臨床的 に，てれが主徵となる症例は Steroid myopathy と呼ばれて，近時注目されている ${ }^{12)^{23}}$.

既に Glucocorticoid には，大要次の様な生理作用のあることが明らかとされている ${ }^{45(5) 6}$. (1)基礎代謝の 維持, (2)グルコースならびそグリコーゲンの新生, (3)体組織蛋白の異化と肝臓蛋白の同化, (4)脂肪合成の抑 制と貯臟脂肪の動員, この内(2), (3)はりわけ詳細に解析されて, 近時生化学的にもその輪郭がかなり明確 に浮きぼりにされてきた。

従つて Steroid myopathy は, この(3の作用で䓯起された現象の状態名とでも言えようが，臨床報告例 での筋侵襲の程度には筋の種類で差異があり, 各筋の組織蛋白を, 一様に体蛋白という範疇に入れては, Steroid myopathy の特異な Figure は理解され得ない.

そこで著者は Prednisolone を白鼠や家鬼に投与して, まず動物に Creatinuria を招来させ，その発生 機転を筋侵襲との関連において揻え乍ら, Glucocorticoid 投与下での侵襲筋の特徴に考察を加えて ${ }^{2}$, Steroid myopathy の臨床像の実体を把握しようと試みてみた，

\section{II 実 験 方 法}

\section{1) 被検動物}

体重120～130gmの吞竜系雄性白鼠，及び体重 2 $3 \mathrm{~kg}$ の雄性家鬼を用いた.

2) Creatine-1-C ${ }^{14}$ の注入法

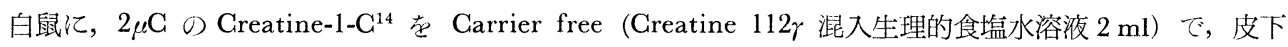
注入した.

3) Prednisolone の投与法

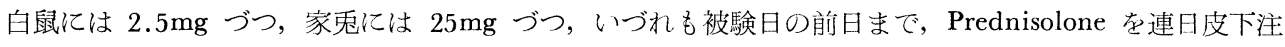
入した。

\section{4) Creatine の負荷法亡. その回収率の計算}

Prednisolone 非投与，連続投与 8 日目，18日目の家兔に，それぞれ体重 $1 \mathrm{~kg}$ 当り30mg Creatine (生 理的食塩水 $2 \mathrm{ml}$ 液) を皮下注入し, その前後 3 日間の尿の Creatine を測定して, 次の様な計算式で, Greatine の回収率を求めた。

$$
\text { 回収率 }=\frac{(3)-(2)}{(1)} \times 100
$$

（1） Creatine 0 負荷量 
（2）負荷前 3 日間の尿中の Creatine 量

(3) 負荷後 3 日間の尿中の Creatine 量:

\section{5 ) 諸種物質の測定までの操作}

動物を断頭屠殺して充分に脱血させ, 各藏器を取り出して生理的食塩水で洗滌し, その湿性重量 $1 \mathrm{gm}$ 亿 $10 \mathrm{ml}$ の溜水を加えてホモジナイズ後, 遠沈 (104r. p.m., 10分) を行ない, その上清を水溶性区画とした。 次いでその沈渣に $10 \mathrm{ml}$ の $0.1 \mathrm{M} \mathrm{KGl}$ 溶液を加えて攪拌後 1 時間放置し，その遠沈（上記の回転数）上清 を $0.1 \mathrm{M} \mathrm{KGl}$ 溶出区画，更にその沈渣に $10 \mathrm{ml} の 0.6 \mathrm{M} \mathrm{KGl}$ 溶液を加えて攪䢁後 over night 放置し， その遠沈上清を $0.6 \mathrm{M} \mathrm{KGl}$ 溶出区画と, 同様の操作を続けて（放置時間は 1 時間）順次 1.0M, 2.0M, 4.0M 各 KGI 溶出区画を得て行き, 最後の residue を加えて, 組織を都合 7 区画に分画した. (以上の操作は総 べて $0{ }^{\circ} \mathrm{C} て ゙$ 行ない, 又使用した $\mathrm{KGl}$ 溶液にはいづれも $5 \times 10^{-2} \mathrm{M}$ Tris-HCl Buffer -pH 9.0- を含有させ ている).

\section{6 ) 諸種物質の測定法}

i 尿中・組緇中の Creatine 及び Creatinine

被検材料に Trichlor acetic acid を添加（終濃度10\%)して除蛋白後, その上清の Greatine, Greatinine を Folin 法7)を用いて定量した.

ii Creatine-1-C ${ }^{14}$ の放射活性

各臟器の水溶性区画中の放射活性を, Windowless gas flow counter で, Infinite thickness として測 定し，それに自己吸収補正を加えて求めた。

iii 蛋白量は Biuret 法帛で, Myoglobin 量は津島法9)で, Creatine Kinase 活性は Noda 法 ${ }^{10)}$ で, Aldolase 活性は水溶性及び $0.1 \mathrm{M} \mathrm{KCl}$ 溶出区画を被検材料に用い, Sibley-Lehninger 法 ${ }^{11)}$ で，LDH 活性は水溶性及

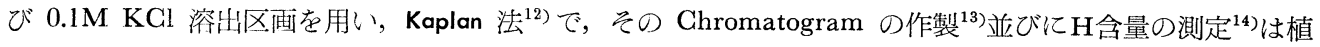
田法で, Myosin ATPase 活性は Barany 法 $^{15)}$ で，それぞれ測定した.

\section{III 結果並びに考案}

\section{Prednisolone の投与と Creatinuria}

Glucocorticoid は，その種類を問わず，大なり小なり筋肉の瘦せと筋力の低下を招来する。当ホルモンは， 現在では薬剤として, 種々の疾患の治療に広範囲に利用されているので, 実の所当然ての様な筋障碍の発生 頻度も高くなつているのであろう。しかしそれに関する知見は極めてそしい.

1959年, Perkoff 等 ${ }^{3}$ は, Steroid の投与に伴い典型的な筋障碍のみられた 7 例を集めて臨床報告を行ない, Steroid の所謂 Iatrogenic disorder の一つとしてのかかる筋症への，世人の関心を喚起している。その彼 等の症例では， Cortisone 又は Predonisone の長期の投与で，腰筋及び下肢筋に萎縮と筋力の低下が現わ れ，且つそれに伴い，血清や尿に Creatine の濃度の上昇や排泄の增加がみられている。

何故 Steroid で筋に障碍がおこるのか. 強い変化か現れる筋は，どんな一般特性をもつているのか. Creatinuria はこの筋障碍とどんな関係があるのか といつた本症の発生機作を解く諸問題に対する解答は, しかしそこには与えられていない，その為著者は Glucocorticoid を投与して， Greatinuria を招来させ，

この Creatinuria の発生機転の追跡に，まず本泟解析への端緒を求めてみた.

今, 雄性家鬼に, Prednisolone t $25 \mathrm{mg}$ づつ連日投与して，その尿中の Creatine/Creatinine 比をみて 行くと, 投与の前日では 0.1 , 第 2 日目は 0.6 , 第 4 日目は 0.8 , 第 6 日目は 1.2 , 第 8 日目は 0.9 , 第 10 日目は 1.3 , 第12日目は1.3, 第14日目は1.6, 第16日目は3.9（いづれも, 兔 3 羽の平均）となつて, その値には漸 増が認められた。

又 Greatine 排泄の絶対量を，乙れ等の家鬼で Prednisolone 投与前，連日投与 6 〜 8 日目，16〜18日目 と比較しても, その值は, それぞれ 8.7, 110.2, 108.7mg/3days/rabbit となつて (Table 1), Creatine の尿 中への排泄量は，確かに Prednisolone で増加している。 
一般に Creatinuria はどうしておてつて来るの だろうか。哺乳動物では， Greatine は督および 肝を経て合成がなされ，そして筋で眝臟されると

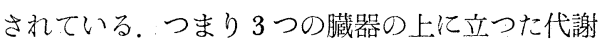
が， Creatine では営まれているので，これらの 個々の臓器の障碍では勿論のとと, 単に臟器相関 がてわされただけでも，当然 Creatine 代謝にそ の影響がもたらされて来よう。

では，Steroid 投与の場合にはどうなつている のか，それは合成系の促進によつているのか，そ れとも貯蔵系の減衰によつているのであろうか. 先程の 3 群の家鬼に, 体重 $1 \mathrm{~kg}$ 当り $30 \mathrm{mg}$ の Creatine を負荷して，その何\%が尿中で回収される かをまずみてみた。
Fig. 1. Prednisolone and urine creatine/creatinine

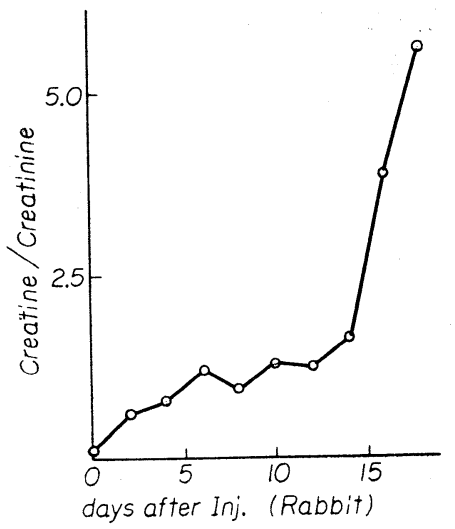

Table 1. Prednisolone effect on creatine tolerance

\begin{tabular}{|c|c|c|c|c|c|c|}
\hline $\begin{array}{c}\text { Total Urine } \\
\text { Greatine } \\
\text { for 3days } \\
\text { Days after Inj. }\end{array}$ & $\begin{array}{c}\text { Exp. } \\
\text { No. }\end{array}$ & $\begin{array}{c}\text { Creatine } \\
\text { loaded } \\
\text { (1) }\end{array}$ & $\begin{array}{l}\text { Before } \\
\text { Loading } \\
\text { (2) }\end{array}$ & $\begin{array}{l}\text { After } \\
\text { Loading } \\
(3) \\
\end{array}$ & $\begin{array}{l}\text { Excretion } \\
(3)-(2) /(\end{array}$ & $\begin{array}{l}\text { Percent. } \\
\times 100\end{array}$ \\
\hline 0 & $\begin{array}{l}1 \\
2 \\
3\end{array}$ & $\begin{array}{l}75 \\
96 \\
78\end{array}$ & $\begin{array}{r}10.5 \\
9.6 \\
6.0\end{array}$ & $\begin{array}{l}19.4 \\
17.8 \\
15.0\end{array}$ & $\left.\begin{array}{r}13.2 \\
7.9 \\
11.5\end{array}\right)$ & 10.8 \\
\hline 8 & $\begin{array}{l}1 \\
2\end{array}$ & $\begin{array}{r}66 \\
64.5\end{array}$ & $\begin{array}{l}109.4 \\
111.1\end{array}$ & $\begin{array}{l}162.2 \\
181.6\end{array}$ & $\left.\begin{array}{r}79.8 \\
109.0\end{array}\right)$ & 94.4 \\
\hline 18 & $\begin{array}{l}1 \\
2 \\
3\end{array}$ & $\begin{array}{l}51 \\
60 \\
51 \mathrm{mg}\end{array}$ & $\begin{array}{c}56.5 \\
107.1 \\
162.6 \mathrm{mg}\end{array}$ & $\begin{array}{l}108.0 \\
135.6 \\
199.6 \mathrm{mg}\end{array}$ & $\left.\begin{array}{r}100.9 \\
56.0 \\
72.5\end{array}\right)$ & 76.5 \\
\hline
\end{tabular}

Creatine loading $30 \mathrm{mg} / \mathrm{kg}$ body weight

(Rabbit)

その結果は非投与群では 10.8\%，Prednisolone 連日投与 6 日目では $94.4 \% ， 18$ 日目では76.5\%となり， 高率な回収率が投与群で得られた。したがって，Creatinuria は Steroid の投与で貯蔵系の減弱がおてり， その結果として招来されて来たものと一応理解されよう.

\section{Creatine の貯臓系減弱の意味}

さて貯臓系の減弱であるが，それは一体何を意味しているのであろうか. それには，如何なる仕組みで， 筋は Creatine を貯藏しているのかが，まず知られなければなるまい．そてでての点を Isotope 店いた実 験で解析してみた。

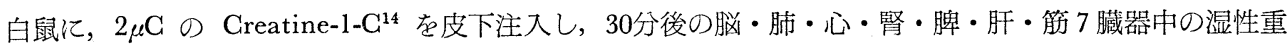
量当りの放射活性を測定してみると，それぞれ $14,198,228,833,90,241,170 \mathrm{cpm}$ ( 2 例の平均) となり， 一応脳を除く 6 藏器中に, 有意の活性が検出される。したがつて，ての結果から取込みの点で，特別の仕組 みを筋が持つているのだとの想定はまず否定される。とてろでその放射活性の推移を更に 6 時間，20時間と みて行くと, 筋・心・脳の 3 藏器のみの放射活性に漸増が, 逆にそれ以外の肺・腎・脾・肝 4 藏器には漸減 
Fig. 2. Distribution pattern of ${ }^{14} \mathrm{C}$-creatine

\begin{tabular}{|c|c|c|c|}
\hline Tissue & $\begin{array}{l}\text { Exp. } \\
\text { No. }\end{array}$ & $\begin{array}{l}\text { cpm/w.w.g. } \\
2.5 \times 10^{4}\end{array}$ & $5.0 \times 10^{4}$ \\
\hline Brain & 2 & & \\
\hline Lung & 2 & कासm & \\
\hline Heart & 2 & mommit| & \\
\hline Kidney & 2 & 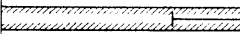 & \\
\hline Spleen & 2 & mist & \\
\hline Liver & 2 & титлтा & \\
\hline $\begin{array}{l}\text { Skeletal } \\
\text { Muscle }\end{array}$ & 2 & mammits & \\
\hline
\end{tabular}

Table 2. Total creatine in tissue

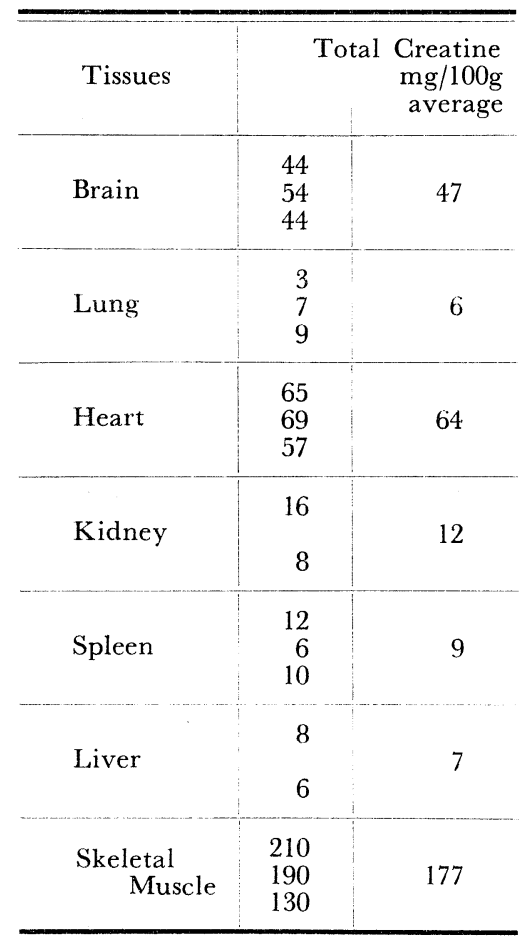

(Rat)
Fig. 3. Radioactivities $\left(\times 10^{4} \mathrm{cpm} / \mathrm{w} . w . g\right)$ and hrs. after injection

\begin{tabular}{|c|c|}
\hline Tissue & $\begin{array}{l}6 \text { hrs. (3cases) } 20 \text { hrs. (3cases) } 44 \text { hrs. (2 cases) } \\
\begin{array}{llll|ll|l}1.0 & 2.0 & 3.0 & 1.0 & 2.0 & 1.0 & 2.0 \\
\end{array}\end{array}$ \\
\hline Brain & \\
\hline Lung & \\
\hline Heart & \\
\hline Kidney & \\
\hline Spleen & \\
\hline Liver & 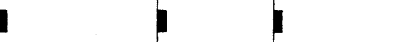 \\
\hline $\begin{array}{l}\text { Skeietai } \\
\text { Muscle }\end{array}$ & \\
\hline
\end{tabular}

(Rat)

Table 3. Creatine kinase in tissue

\begin{tabular}{|c|c|c|}
\hline Tissues & & $\begin{array}{l}{ }^{\text {vities }} \\
{ }^{3} \mu \text { moles } / \\
\text { hr./w.w.g. } \\
\text { average }\end{array}$ \\
\hline Brain & $\begin{array}{l}4.5 \\
3.0 \\
4.5\end{array}$ & 4.0 \\
\hline Lung & $\begin{array}{l}0.16 \\
0.14 \\
0.19\end{array}$ & 0.16 \\
\hline Heart & $\begin{array}{l}3.4 \\
2.7 \\
3.0\end{array}$ & 3.03 \\
\hline Kidney & $\begin{array}{l}0.42 \\
0.15 \\
0.36\end{array}$ & 0.31 \\
\hline Spleen & $\begin{array}{l}0.26 \\
0.33 \\
0.56\end{array}$ & 0.38 \\
\hline Liver & $\begin{array}{l}0.49 \\
0.33 \\
0.18\end{array}$ & 0.33 \\
\hline $\begin{array}{l}\text { Skeletal } \\
\text { Muscle }\end{array}$ & $\begin{array}{l}31 \\
35 \\
31\end{array}$ & 33.5 \\
\hline
\end{tabular}

(Rat)

が招来されて来た。っして44時間後には，各臟器の活性はそれぞれ $60,36,385,56,48,39,523 \mathrm{cpm}$ となり， その分布像は, 所謂総 Creatine の分布像 (-Table 2- 別の白鼠の各臟器を用い, その中の Creatine の総含 量を求めてえられた）之極めて類似している。したがつて, 取り込み実験のてれらの一連の知見から, 組織 へ入つた Creatine を, 外一出難くする点に問題があるととにしぼられた.

ところで, Table 3 は, 上記 7 藏器中の Creatine Kinase 活性の強さを示している。 今てれを Tadle 2 と比較してみると, Creatine Kinase 活性が強い臓器では, いづれも Creatine の総含量 (Creatine+Creatine 燐酸)も多くなつているととに気付かれる。即ちことにおいて，組織での Creatine の貯臟量は，一 
度細胞内に入つた Creatine を, 細胞膜を通つて出て行けない型(その燐酸型) となしうる Creatine Kinase が，その組織にどれだけあるかで決つてくるという結論が導かれて来よう。これは，1964年 Eppenberger 等 の示した個体発生途上のニワトリ筋での成績 ${ }^{16}$ ) (筋発育に伴う燐酸クレアチン含量の増量は，筋 Creatine Kinase 活性の上昇と併行している））と矛盾するものではない.

したがつて Creatine の䝪臟系の減弱は，つまり体内の総 Creatine Kinase 活性の減少を示唆している.

\section{Prednisolone の投与と, Creatine の筋貯臟系}

実際そうなつているかを，そてで検討してみた。

$123 \mathrm{gm}$ の平均体重（3 匹）をもつ吞竜系雄性白 鼠に，基本食を与え乍ら経時的に体重を測定して 行くと，2日目には，134gm，4日目には141gm， 6 日目には $153 \mathrm{gm}, 8$ 日目には161gmと，そこに 定常的な体重増加が追跡され得る。ところが，実 験開始日 $125 \mathrm{gm}, 2$ 日目 $138 \mathrm{gm}$, と後同じ比率 の体重増加がみられて行くであらう動物群 ( 3 匹) 飞, Prednisolone を毎日 $2.5 \mathrm{mg}$ づつ腹腔内注 入したものでは，4 日目，126gm，6日目 $121 \mathrm{gm，}$ 8 日目 $119 \mathrm{gm}$ と，逆にその体重に減少がみられ

Fig. 4. Effect of prednisolone on organ weight

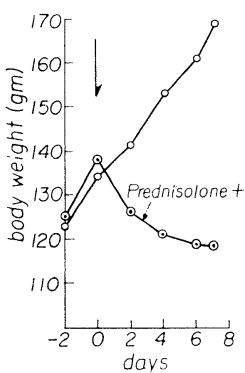
た. (Fig. 4. 左)

この Prednisolone 投与開始後 7 日目で, 両群の動物を脱血死させ，ただちに肝・筋を取り出して，その 湿性重量を Prednisolone 非投与群と投与群とで比較すると, (Fig. 4. 右), 後者の体重には著明な減少が 招来されて（前者：161gm, 後者: $119 \mathrm{gm}$ ) いるのに, 肝重量ではかえつて増加が（前者: $7.2 \mathrm{gm}$, 後者: $8.0 \mathrm{gm})$, 一方筋重量には体重之同傾向の減少が認められていた。

かかる筋内には，どんな変化がおてつているのかをより詳細に知る為に，そてで $2 〜 3 \mathrm{~kg}$ の体重を持つ 雄性家鬼を被検動物に用いて実験を進めてみた。

Table 4.は, 毎日25mgづつ Prednisolone を皮注し, その Creatine Kinase 活性並びに Creatine 含量 の筋内の動きを, 経日的に追跡した結果である。（）には, Creatine Kinase 活性及び Creatine 含量の 湿性重量当りの実測值を，その上の数值には非投与時の実測值を 100 と置いた\%を，それぞれ記している。 背筋・腓腹筋・ヒラメ筋・横隔膜笳特に前 2 者では, Creatine Kinase 活性に, Creatine 含量とほぼ平行し

Table 4. Effect of prednisolone on tissue creatine kinase and creatine

\begin{tabular}{|c|c|c|c|c|c|c|c|c|c|}
\hline & \multicolumn{5}{|c|}{ Creatine Kinase $\mu$ moles/min./w.w.g. } & \multicolumn{2}{|c|}{ Creatine } & \multicolumn{2}{|c|}{$\mathrm{mg} / \mathrm{w} \cdot \mathrm{w} \cdot \mathrm{g}$} \\
\hline days & 0 & 3 & 8 & 15 & 17 & 0 & 3 & 8 & 15 \\
\hline Backmuscle & $\begin{array}{c}100 \\
(732) \\
\end{array}$ & $\begin{array}{r}65 \\
(476) \\
\end{array}$ & $\begin{array}{r}87 \\
(640) \\
\end{array}$ & $\begin{array}{r}59 \\
(429) \\
\end{array}$ & $\begin{array}{r}70 \\
(510) \\
\end{array}$ & $\begin{array}{c}100 \\
(2.70) \\
\end{array}$ & $\begin{array}{r}87 \\
(2.34) \\
\end{array}$ & $\begin{array}{r}92 \\
(2.48) \\
\end{array}$ & $\begin{array}{r}71 \\
(1.93) \\
\end{array}$ \\
\hline Gastrocnemius & $\begin{array}{r}100 \\
(630) \\
\end{array}$ & $\begin{array}{r}85 \\
(531) \\
\end{array}$ & $\begin{array}{c}91 \\
(572) \\
\end{array}$ & $\begin{array}{r}78 \\
(494) \\
\end{array}$ & $\begin{array}{r}68 \\
(429) \\
\end{array}$ & $\begin{array}{r}100 \\
(2.54) \\
\end{array}$ & $\begin{array}{r}92 \\
(2.34) \\
\end{array}$ & $\begin{array}{r}97 \\
(2.47) \\
\end{array}$ & $\begin{array}{r}83 \\
(2.11) \\
\end{array}$ \\
\hline Soleus & $\begin{array}{c}100 \\
(314) \\
\end{array}$ & $\begin{array}{c}125 \\
(395) \\
\end{array}$ & $\begin{array}{r}80 \\
(252) \\
\end{array}$ & $\begin{array}{r}79 \\
(243) \\
\end{array}$ & $\begin{array}{r}71 \\
(221) \\
\end{array}$ & $\begin{array}{r}100 \\
(1.67)\end{array}$ & $\begin{array}{r}93 \\
(1.55) \\
\end{array}$ & $\begin{array}{r}93 \\
(1.55) \\
\end{array}$ & $\begin{array}{r}104 \\
(1.75) \\
\end{array}$ \\
\hline Diaphragm & $\begin{array}{c}100 \\
(304) \\
\end{array}$ & $\begin{array}{c}116 \\
(359) \\
\end{array}$ & $\begin{array}{c}81 \\
(255) \\
\end{array}$ & $\begin{array}{r}77 \\
(232) \\
\end{array}$ & $\begin{array}{r}90 \\
(273) \\
\end{array}$ & $\begin{array}{r}100 \\
(1.85) \\
\end{array}$ & $\begin{array}{r}99 \\
(1.83) \\
\end{array}$ & $\begin{array}{r}95 \\
(1.76) \\
\end{array}$ & $\begin{array}{r}84 \\
(1.55) \\
\end{array}$ \\
\hline Heart & $\begin{array}{c}100 \\
(196)\end{array}$ & $\begin{array}{r}112 \\
(238) \\
\end{array}$ & $\begin{array}{c}101 \\
(199) \\
\end{array}$ & $\begin{array}{c}109 \\
(213) \\
\end{array}$ & $\begin{array}{c}100 \\
(195) \\
\end{array}$ & $\begin{array}{r}100 \\
(1.14) \\
\end{array}$ & $\begin{array}{r}99 \\
(1.11) \\
\end{array}$ & $\begin{array}{r}99 \\
(1.08) \\
\end{array}$ & $\begin{array}{r}110 \\
(1.24) \\
\end{array}$ \\
\hline
\end{tabular}

(Rabbit) 
た漸減傾向が認められている。したがつて，乙れ亿筋の湿性重量にも減少がみられた Fig. 4 の結果を合せ ると，Prednisolone の投与で Creatine Kinase 総量の顕著な減少が，実際招来されて来るととが確認され た.

\section{4 侵襲の程度と筋の種類}

Prednisolone に上る筋侵襲の特長の 1 つは, 筋の種類でその程度が異つているてとである，筋の湿性重 量を比較した Fig. 4 の成績では, 腓腹筋には $30 \%$ の減少がみられているのに，ヒラメ筋にはその影響は 6 \%と殆んぞ及んでいない，又被検筋の種類を增して活性や Creatine 含量の推移を追つている Table 4 を みても, 減少は, 各筋均一にはおてつていない。

とてろで, 筋を背筋・腓腹筋・ヒラメ筋・横隔膜筋・心筋と並べると, Creatine Kinase 活性も, Creatine 含量も, その減少の程度は前の筋程強く現われて来ている, 同じ現象は又 Aldolase 活性にも認められ た. (Table 5)

Fig. 5 は, 実験方法 5 で述べた KCl 分 画法を用いて, 家鬼筋組織を7区画に区 分し, 各区分の蛋白量を Column で現 わした場合の Protein pattern を示す. Prednisolone の連日投与の影響が，如 何なる筋の, 如何なる区分に強く現われ て来るかをみるために，上から背筋・腓 腹筋・ ヒラメ筋・ 心筋, 右へ, 対象” Prednisolone を $25 \mathrm{mg}$ づつ連日投与し た 3 日目，その15日目と並べているが， やはりとの場合にも上段程強い変化が， 特に水溶性おけび $0.6 \mathrm{M} \mathrm{KGl}$ 溶出区画 で顕著に現われていた。

Fig. 6 は, 各 KGl 溶出区画中の Ca-

Table 5. Effect of Prednisolone on Muscle Aldolase

\begin{tabular}{|c|c|c|c|c|}
\hline Tissues days & 0 & 3 & 8 & 15 \\
\hline Backmuscle & $\begin{array}{c}100 \\
(425)\end{array}$ & $\begin{array}{r}95 \\
(396) \\
\end{array}$ & $\begin{array}{r}75 \\
(320) \\
\end{array}$ & $\begin{array}{r}45 \\
(191) \\
\end{array}$ \\
\hline M. gastrocnemius & $\begin{array}{c}100 \\
(360) \\
\end{array}$ & $\begin{array}{r}91 \\
(328) \\
\end{array}$ & $\begin{array}{r}68 \\
(243) \\
\end{array}$ & $\begin{array}{r}32 \\
(114) \\
\end{array}$ \\
\hline M. soleus & $\begin{array}{r}100 \\
(87) \\
\end{array}$ & $\begin{array}{r}82 \\
(71) \\
\end{array}$ & $\begin{array}{r}52 \\
(45) \\
\end{array}$ & $\begin{array}{r}49 \\
(43) \\
\end{array}$ \\
\hline Diaphragm & $\begin{array}{r}100 \\
(176) \\
\end{array}$ & $\begin{array}{r}89 \\
(157) \\
\end{array}$ & $\begin{array}{c}84 \\
(148)\end{array}$ & $\begin{array}{r}50 \\
(88) \\
\end{array}$ \\
\hline Heart & $\begin{array}{r}100 \\
(44) \\
\end{array}$ & $\begin{array}{r}84 \\
(37) \\
\end{array}$ & $\begin{array}{r}98 \\
(43) \\
\end{array}$ & $\begin{array}{r}107 \\
(47) \\
\end{array}$ \\
\hline
\end{tabular}

ATPase 活性を, Barany 法 $^{15)}$ を用いて 測定した結果である. 左から 3 番目の Column ( $0.6 \mathrm{M} \mathrm{KGI}$ 溶出区画) には Myosin が含有されているの で，特にその活性は高く出ている。（Fig. 6 左）しかし Prednisolone の連日投与15日目（Fig.6 右）では， 腓腹筋，ヒラメ筋のその活性は殆んど無くなつているが，心筋では，それ程低下していない．

したがつて，乙れらの一連の知見をまとめると，Steroid で，筋は単に Creatine Kinase のみに止まら ず，殆んぞその全蛋白首にわたつて侵襲され，それが心筋・横隔膜筋・ヒラメ筋・腓腹筋・背筋の順序で強 くあらわれるとの結論とならう。

\section{Steroid 侵襲と白筋}

上記の筋の順序は，一体何を意味しているのであろうか. Table 6 は，てれらの筋で組成を検討した植田 ・永原等の成續 2 17) である.

LDH 活性, Aldolase 活性, Creatine Kinase活性, Creatine 量, Myosin ATPase の pH 7.4 での活 性に対する $\mathrm{pH} 9.1$ での活性の比は, いづれも上段程多くなつている. 反対に LDH の H\%, Myoglobin 量, Succinic dehydrogenase 活性, 総 GPT の内のミトコンドリャ GPT の占める割合, 総 GOT の 内のミトコンドリヤ GOT の占める割合はいづれも上段程少くなつている. 今最上段の背筋と, 最下段の 心筋とを比較してみると, 前者では phasic な敏速な運動が，後者では tonic な持続運動が行なえるよう， 各組成が合目的に折り込まれているてと吾代気付かれよう。

したがつて，同心順序に並べて Steroid の影響をみた Table 4, 5, Fig. 5, 6 の結果は, phasic な敏速 運動がしやすい筋，一Myoglobin やSuccinic dehydrogenase の様な鉄蛋白が少なくて赤味が芝しくな 
Fig. 5. Effect of prednisolone on muscle protein pattern
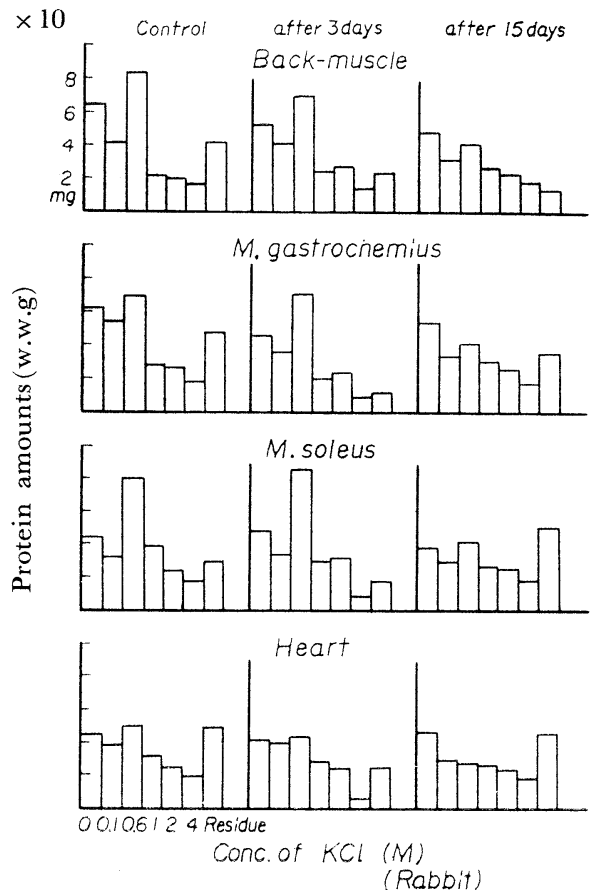

Fig. 6. Effect of prednisolone on Ca-ATPase

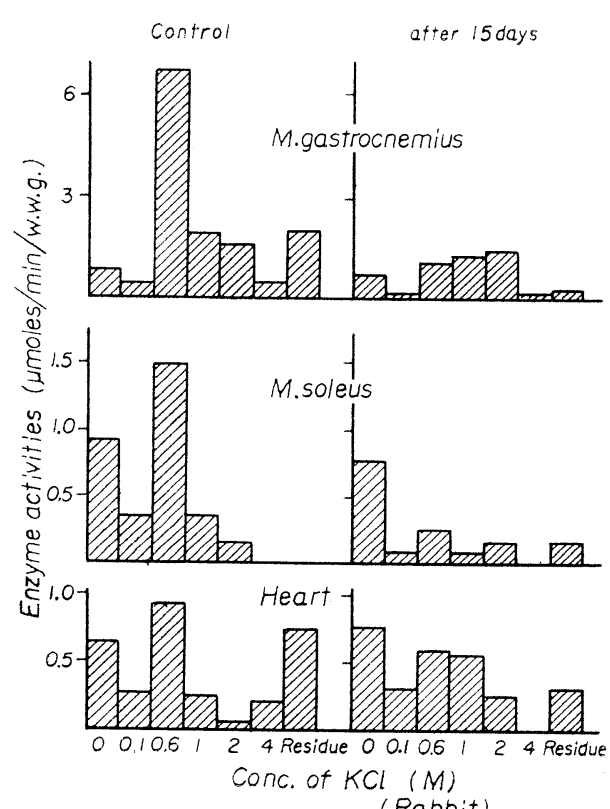

(Rabbit)

Table 6 Contents in various muscles

\begin{tabular}{|c|c|c|c|c|c|c|c|c|c|c|}
\hline \multirow[b]{2}{*}{ Backmusche } & \multicolumn{2}{|c|}{$\begin{array}{c}\text { LDH } \\
\text { H\% } \begin{array}{l}\text { Total } \times 10^{4} / \\
\text { w.w.g } \\
\text { Wroblewski }\end{array}\end{array}$} & \multirow{2}{*}{$\begin{array}{l}\begin{array}{c}\text { Aldolase } \\
\mu \mathrm{M} / \mathrm{min} . \\
/ \mathrm{w} . \mathrm{w} . \mathrm{g} .\end{array} \\
460\end{array}$} & \multirow{2}{*}{ 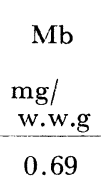 } & \multirow{2}{*}{$\begin{array}{c}\begin{array}{l}\text { Succinic } \\
\text { Dehydro } \\
\text { genase }\end{array} \\
0.2\end{array}$} & \multirow{2}{*}{ 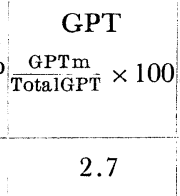 } & \multirow{2}{*}{$\begin{array}{c}\text { GOT } \\
\frac{\text { GOT } m}{\text { TotalGOT }} \times 100 \\
4.5\end{array}$} & \multirow{2}{*}{$\begin{array}{c}\begin{array}{c}\text { Creatine } \\
\text { Creatine } \\
\text { mg/ } \\
\text { w.w.g. }\end{array} \\
2.7\end{array}$} & \multirow{2}{*}{$\begin{array}{c}\text { System } \\
\mathrm{GPK} \\
\mu \mathrm{M} / \mathrm{min} . \\
/ \mathrm{w} . \mathrm{w} . \mathrm{g} . \\
732\end{array}$} & \multirow{2}{*}{$\begin{array}{c}\begin{array}{c}\text { Myosin } \\
\text { pH9.1 }\end{array} \\
\text { pH7.4 } \\
3.09\end{array}$} \\
\hline & 2.6 & 14.4 & & & & & & & & \\
\hline $\begin{array}{l}\text { Gastro- } \\
\text { cnemius }\end{array}$ & 5.9 & 9.2 & 381 & 0.84 & 0.5 & 9.7 & 8.3 & 2.5 & 630 & 3.05 \\
\hline Soleus & 52.0 & 3.4 & 164 & 2.52 & 0.9 & 11.5 & 11.9 & 1.7 & 314 & 2.22 \\
\hline Diaphragm & 49.0 & 5.3 & 218 & 2.02 & 2.3 & 12.3 & 12.2 & 1.9 & 304 & 2.53 \\
\hline Heart & 92.0 & 3.4 & 60 & 3.64 & 9.9 & 19.8 & 20.1 & 1.1 & 196 & 0.95 \\
\hline
\end{tabular}

(Rabbit)

つている白筋一一程，Steroid で影響をうけやすいととを示唆している.

ではヒトの場合はどうであろうか，Cushing 症候群では，通常丸い顔，太い首，肥満した軀幹，それに 瘦せた四肢が認められる，脂肪沈着のために，顔・首・軀幹筋の様相は定かではないが，症状には，立ち上 がれない，鉛筹が持てないということはあつても，呼吸ができない，心不全がおこつたという報告は未だ見 当らないので，ヒトの場合の筋障碍は軀幹筋より四肢筋に強くおてつている。

Fig. 7 はヒ卜筋 LDH の DEAE Sephadex A-50 Column chromatogram である. Fig. でみられる通 りその Pattern には筋の種類で差異がみられ, Deltoideus, Quadriceps femoris, Gastrocnemius, Tibialis 
anterior には所謂 $\mathrm{M}_{4}$ Typeの, Pectoralis major, Transversus abdominis には $\mathrm{H}_{2} \mathrm{M}_{2}$ Type の，心 筋には $\mathrm{H}_{4}$ Type の LDH が多くなつている。この 前の四つの筋はいづれも四肢にある。

したがつて，上記の Steroid の罹患筋を，その LDH Isozyme の組成を中に拈いて，Table 6 で同 定してみると，M含量の多い(これはH含量が少い) 筋 $\rightarrow$ 上段の筋 $\rightarrow$ 白筋となり，やはりヒトでも，白筋 程強い陪碍が招来されてくるとの結論へ導かれた。

Glucocorticoid は，体内で合成される内因性の活 性物質であつて，生体にとつての異物ではない，し たがつて，以上の知見を合目的な見方で結び合せて 行くと，次のように要約されよう.

即ち，外界からのストレスが生体にあたれば，間 脳一下垂体一副婜系が作動して, Glucocorticoid が 分泌される。外から栄養素が補給されない場合, 乙 の Steroidは, ある種の体蛋白を消耗し，その犠牲 のもとに肝にエネルギー源を集め，その機能を高め て生命活動は全とうされる。年の際重舅の点からい つても, 体蛋白としての筋蛋白の占める役割は大き

い.しかし異化の対象となりらるものは，所謂“動き”に関与している筋蛋白であつて，生命保持に值接関 係している重力筋や烀吸筋や心筋蛋白は，それから除外されている。つまり，ストレスに対する防禦体制之 して，生体は動物本来の特性である“動き”を消失させ，その犠牲て生命が保持される仕組みをとつている。 それが Steroid の白筋侵襲の意味ととれよう。

Glucocorticoid と白筋侵襲一雨者はどう結びついているのか. その問に介在している仕組みは何か，尚興 味ある課題は残されている。

\section{IV 結 語}

1，家鬼に Prednisolone を $25 \mathrm{mg}$ づつ連日投与して行くと, Creatinuria がみられる。それは眝臟系の 減弱によつているととが, Creatine の負荷試験の結果, 明らかとされた。

2 Greatine 貯蔵の仕組みは, 取り込んだ Creatine を細胞膜を通つて出て行けない燐酸型に転換すること にある事が，白鼠に注入した $\mathrm{C}^{14}$-Creatine の追跡結果から示唆された。

3 Creatine の燐酸化は Greatine Kinase によつている。乙の酵素の活性は, Prednisolone の投与下で は Creatine 含量と併行して減少しており，1，2の知見からみて，てれが Creatinuria の成因の主体と なつている.

4 Prednisoloneの投与下の筋組織内では，上記の Creatine Kinase, Aldolase, Ca-ATPase 活性はいずれ も低下しており，その程度は白筋で強い。

5 Cushing 症候群にみられる症状は，ヒトの場合四肢筋が強く侵襲されてくることを示している。乙れ らの筋はいづれも白筋で構成されていることが，LDH の Isozyme 組成から同定された。

擱筆するにあたり，で指導及びご校閲を奨うした恩師西川光夫教授に墚甚な謝意を表し，終始ご指導ご鞭撻 を睗わつた植田㤵嗣博士に敬意をささげ, 種々ので協力をいただいた伏見尚子博士, 岸野文一郎学士, 伊藤 友昭学士, 阪大泌尿器科学教室の永原篤学士に感謝します. 
昭和 40 年12月 第 5 回医化学シンポジゥム発表（福岡）

昭和41年 4 月 第39回日本内分泌学会総会発表（東京）

$$
\mathrm{V} \text { 文献 }
$$

1）西川光夫，植田啓嗣，松本謙二，伏見尚子，中田俊士：日本臨休，22:2517，(1964).

啓嗣，中田俊士，岸野文一郎，伏見尚子，西川光夫：医化学シンポジゥム第 5 集，60，(1965).

3) PERKOFF, G.T., SIlbER, R., TYLER, F.H., GARTWRIGHT, G.E. and WINTROBE, M.M. : Am. J. Med., $26: 891$, (1959).

4) 嶋津孝: 蛋白質・核酸・酵素, $7: 303$, (1962).

WEBER, G., SRIVASTAVA, S.K. and SINGHAL, R.L. : J. Biol. Chem., 240 : 750, (1965).

WEBER, G., SINGHAL, R.L., STAMM, N.B. and SRIVASTAVA, S.K. : Fed. Proc., 24 : 745, (1965).

7）宮崎英策, 内田倖喜, 小西和彦：化学の領域（光電比色法）各論 2, (1958), 94, 西江堂, 東京.

8) LAYNE, E. : Method in Enzymology, 3, (1957), 450, Acad. Press Inc., N.Y.

9) 津島慶三, 岡崎太郎：生化学, $26: 232,(1954)$.

10) NODA, L., KUBY, S. and LARDY, H. : Method in Enzymology, 2, (1955), 605, Acad. Press Inc., N.Y. 11) SIBLEY, J.A. and LEHNINGER, A. : J. Biol. Chem., 177 : 859, (1949). 12) KAPLAN, O.N., and GAHN R.D. : Proc. Natl. Acad. Sci., 48,2123, (1962). 13) 植田啓嗣, 伊藤友昭, 伏見尚子, 村尾茂雄, 中村正作, 大北速男, 西川光夫 : 医 化学シンポジウム第 3 集, $3: 214$, (1963).

14）植田啓嗣, 伊藤友昭, 中田俊士, 西川光夫 : 医化 学シンポジゥム第 4 集, $4: 151$, (1964).

15) BARANY, M., BARANY, K., RICHARD, T. and VOLPE, A. : Arch. Biochem. Biophys., 109 : 185, (1965). 16) EPPENBERGER, H.M., EPPENBERGER, M., RICHTERICH, R. and AEBI, H. : Develop. Biol., 10 : 1, (1964).

18）植田啓嗣, 伊藤友昭, 中田俊士, 永原篤, 西川光夫 : 日本臨床, $23: 1600$, (1965). 